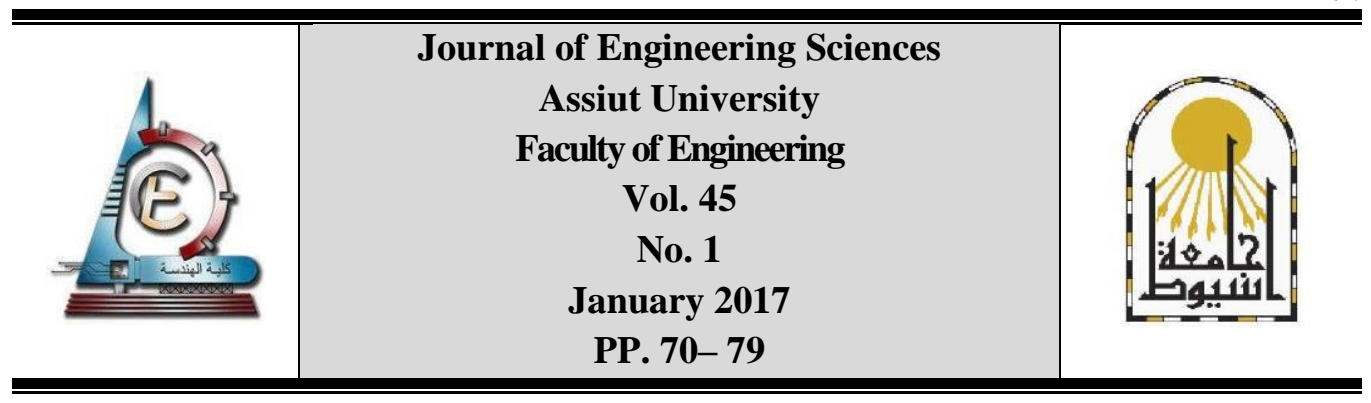

\title{
STABILITY ANALYSIS OF VERTICAL AND INCLINED BACKFILLED STOPE
}

\author{
Wael R. Abdellah ${ }^{1}$ and Mahrous A. Ali ${ }^{2}$ \\ ${ }^{I}$ Mining \& Metallurgical Eng. Depart, Faculty of Engineering- Assiut University, Assiut, Egypt \\ ${ }^{2}$ Mining \&Petroleum Eng. Depart, Faculty of Engineering-Al-Azhar University, Qena, Egypt
}

Received 6 September 2016; Accepted 4 November 2016

\begin{abstract}
Sublevel stoping mining with delayed backfill is a widely employed method in many Canadian underground metal mines (e.g., Bosquet, Doyen, Laronde, and Lapa mines in Quebec and Garson, Creighton, Red lake and David bell mines in Ontario). In this method, the extracted stope(s) must be tightly backfilled before advancing to extract the adjacent secondary stope(s). Thus, backfill is necessary to provide good-confinement to the host rock mass. Therefore, its objective is to maintain the stability of mined out stope(s). Otherwise, the failure of backfill column into adjacent stope(s) leads to higher operation cost (e.g., cost of ore milling/ore processing operation, costs associated with ore dilution when waste/backfill material mixed with unmined block(s)). Consequently, backfill instability could lead to an overall unsafe/interrupt mining operation. This article presents the results of numerical modelling analysis to evaluate the performance stability of vertical and inclined backfilled stope adopting stress state distribution. Two-dimensional finite element model is built to conduct linear elastic analysis employing $\mathrm{RS}^{2 \mathrm{D}}$ program (e.g., formerly known as phase $\mathrm{e}^{2 \mathrm{D}}$ ). The results are presented and discussed in terms of vertical stress and absolute total displacement.
\end{abstract}

Keywords: Backfill performance evaluation, Stress state into backfilled stope, Numerical modelling, sublevel stoping mining system

\section{Introduction}

The backfill term defines the waste material which used for filling an excavation (e.g., mined out stope). It has extensively become a significant element/practice in many Canadian metal mines using sublevel stoping mining system with delayed backfill [1-2]. It is mainly used to provide stope stability (e.g., supports the walls of extracted stope and does not allow further lateral displacement) [3-5]. Also, the uses of backfill in underground mines will reduce the amount of wastes disposed on the surface and therefore protect the mining environment from the hazard of acid mining drainage (e.g., in case of presence of the sulphide minerals). Thereby, it will increase ore recovery by controlling ore dilution [5-7 and 1]. The different purposes to use backfill in underground mines are depicted in Figure 1

\footnotetext{
* Corresponding author.

E- mail address: mahrous_mining@yahoo.co.uk
} 
below [7]. Also backfill is used in the cut-and-fill mining operation to provide working surface and for mucking ore, in open stoping method, from upper stopes [3 and 8]. Backfill can be classified into three groups: hydraulic backfill, paste fill and rock fill [1]. In the next section below, a brief review on the three different categories of the backfill.

\section{Review on backfill types}

As stated above, the definition of backfill means filling mined out stope(s) with waste rock/material. The backfill type is determined according to its composition. For example, hydraulic or slurry backfill composes from permeable, low density blend of mill tailings, sand, rock and water which having an average pulp density from $60-70 \%$ solid by weight [3 and 9]. This type of backfill requires huge binder quantities to substitute the binder seepage out of mined stope(s) with water. Thus, hydraulic or slurry backfill is limited to overhand cut and fill mining operation. The second type of backfill is the paste fill which consists of thickened tailings of the mill with lime, Portland cement, pulverized fly ash and smelter slag. The percentage of solid by weight is $75-80 \%$ in the component of this fill type. Pastefill is widely practiced in sublevel stoping mining system [3 and 10-11]. The third type of backfill is known as rock fill (cemented or uncemented). This type composes from sand/waste rocks obtained from quarries or mine development operations. It does not contain binding agent except that the cement slurry can be injected in later stage to provide consolidation.

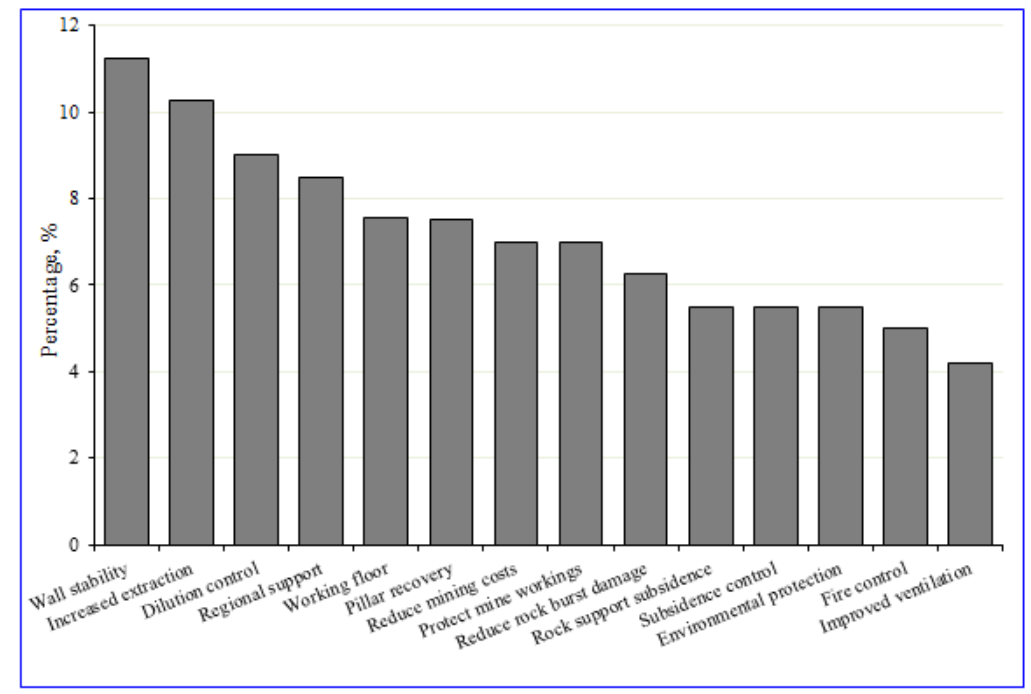

Fig. 1. Purposes of backfilling [7]

Regardless of the types of backfill, they are slightly soft and show low yielding strength compared with the surrounding rock mass. Thus, they may produce large strain (e.g., 5\%) when they placed into mined out stope(s) [12-15]. Some loads may then be induced, as a result of backfill deformation, and transferred along the interfaces between backfill and rock mass (e.g., frictional forces that developed along the contact with the rock mass) [16]. This phenomenon is known as arching effect [17-20]. Therefore, the underground control engineers should be able to adapt a reliable tool that helps measuring/estimating the stress state into and around the backfilled stope(s). The model layout (e.g., geometry and dimensions), for vertical and inclined stope, is introduced in the next section. 


\section{Numerical analysis and model layout}

This analysis is conducted using Rocscience's $\mathrm{RS}^{2 \mathrm{D}}$, a two-dimensional finite element code [21]. The rock mass and backfill properties used in this analysis are listed in Table 1 [22]. The backfill properties represent the cemented rock fill (CRF). Linear elastic analysis, employing Mohr-Coulomb failure criterion, is adopted in this study (e.g., the model's input parameters are: UCS, (unconfined compressive strength), E (Young's modulus), $v$ (Poisson's ratio), $\sigma_{\mathrm{t}}$ (tensile strength) and $\gamma$ (unit weight). The used backfill material is cemented rock fill (CRF) and it obeys an elasto-plastic law with Mohr-Coulomb criterion. CRF properties are described by the values of UCS, E, $v, \sigma_{t}$ and $\gamma$, with the friction angle $\phi=30^{\circ}$, cohesion $\mathrm{C}=1 \mathrm{MPa}$ and dilation angle $\varphi=0^{0}$ ).

Figure 2 shows the model layout for the vertical (e.g., left) and inclined stope (e.g., right) respectively. The stope dimensions are: $(25 \times 5-\mathrm{ms})$; (height $\times$ width), and is located at a depth of $500 \mathrm{~m}$ below the ground surface. A $0.5 \mathrm{~m}$ (height) left as a void space on the top of the stopes (e.g., to limit stress transformation from the top of the backfilled column). The in situ horizontal-to-vertical stress ratio, $\mathrm{K}$, may be calculated from Equations (1, 2 and 3) below [23]. In this analysis, the average horizontal-to-vertical stress ratio is considered and determined using Equation (2). The model is divided into three areas; hanging wall (HW), orebody (stopes) and footwall (FW). The ore body consists of massive sulphide rock (MASU). The hanging wall contains meta-sediments (MTSD) and the footwall comprises of Norite Rock (NR). The simulated mining steps are listed in Table 2.

Table 1.

Rock mass and backfill geomechanical properties [22]

\begin{tabular}{|l|c|c|c|c|}
\hline \multicolumn{1}{|c|}{ Property } & $\begin{array}{c}\text { Hanging wall, HW } \\
(\text { MTSD) }\end{array}$ & $\begin{array}{c}\text { Footwall, FW } \\
(\text { NR) }\end{array}$ & $\begin{array}{c}\text { Ore/stope } \\
\text { (MASU) }\end{array}$ & $\begin{array}{c}\text { Cemented rock fill, } \\
\text { (CRF) }\end{array}$ \\
\hline$\gamma, \mathrm{MN} / \mathrm{m}^{3}$ & 0.02782 & 0.02961 & 0.04531 & 0.02 \\
\hline $\mathrm{UCS}, \mathrm{MPa}$ & 90 & 172 & 90 & 3 \\
\hline $\mathrm{E}, \mathrm{GPa}$ & 25 & 40 & 20 & 0.1 \\
\hline Poisson's ratio, $v$ & 0.25 & 0.18 & 0.26 & 0.30 \\
\hline Tensile strength, $\sigma_{t}, \mathrm{MPa}$ & 0.11 & 1.52 & 0.31 & 0.01 \\
\hline Cohesion, MPa & 4.80 & 14.13 & 10.2 & 1 \\
\hline Friction angle, $\phi,($ degree $)$ & 38 & 42.5 & 43 & 30 \\
\hline Dilation angle, $\varphi,($ degree $)$ & $9(\phi / 4)$ & $10.6(\phi / 4)$ & $11(\phi / 4)$ & 0 \\
\hline
\end{tabular}

$$
\begin{gathered}
K_{\text {max. }}=\frac{\sigma_{\text {hmax }}}{\sigma_{v}}=1.46+\frac{357}{\operatorname{depth}(m)} \\
K_{\text {avg. }}=1.25+\frac{357}{\operatorname{depth}(m)} \\
K_{\text {min. }}=1.1+\frac{\mathbf{1 6 7}}{\operatorname{depth}(m)}
\end{gathered}
$$

By substituting in Equation (2) with $\mathrm{h}=500 \mathrm{~m}$, then the average horizontal-to-vertical stress ratio, $\mathrm{K}_{\mathrm{avg}}$ is calculated as follows:

$$
\mathrm{K}_{\mathrm{avg} .}=\frac{\sigma_{\mathrm{h}}}{\sigma_{\mathrm{v}}}=1.25+\frac{357}{500}=1.96 \cong 2.0 \text {. }
$$

The vertical and horizontal in-situ (e.g., pre-mining) stresses can then be obtained, at $\mathrm{h}=500 \mathrm{~m}$ and average rock mass density of, $\gamma_{\text {avg. }}=0.0287 \mathrm{MN} / \mathrm{m}^{3}$, adopting the following two formulae (e.g., Equations (4) \& (5)) respectively: 
Wael R. Abdellah and Mahrous A. Ali, stability analysis of vertical and inclined backfilled stope

$$
\begin{aligned}
& \boldsymbol{\sigma}_{\mathbf{v}}=\gamma \times \mathrm{h}=0.0287 \times 500=14.35 \mathrm{MPa} \\
& \boldsymbol{\sigma}_{\mathbf{h}}=\boldsymbol{\sigma}_{\mathbf{v}} \times \mathbf{K}_{\text {avg. }}=14.35 \times 2.0=28.70 \mathrm{MPa}
\end{aligned}
$$

Table 2.

The simulated mining steps

\begin{tabular}{|c|l|}
\hline Mining step & Mining activity \\
\hline 1 & Model reaches initial equilibrium \\
\hline 2 & Mine out the primary stope then run the analysis \\
\hline 3 & Backfill the primary stope except $(0.5 \mathrm{~m})$ left as void space at the top of the stope \\
\hline 4 & Mine out the adjacent secondary stope and run again the analysis \\
\hline
\end{tabular}

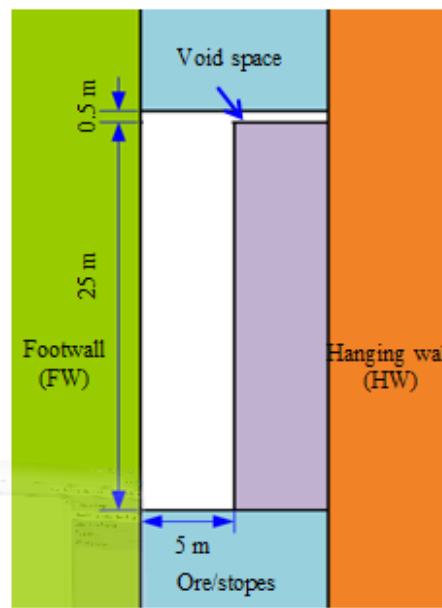

a) Vertical

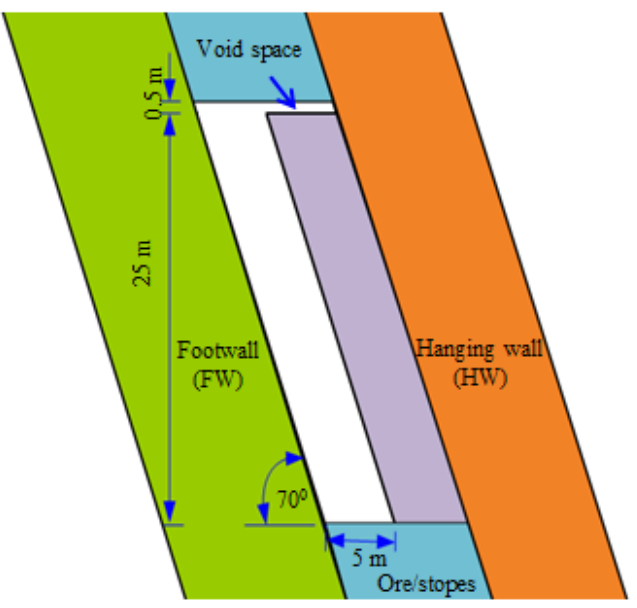

b) Inclined

Fig. 2. The geometry of the vertical (left) and inclined (right) backfilled stope

\subsection{Results and discussion}

The results presented in this paper are obtained under the condition of linear elasticity, even though $\mathrm{RS}^{2 \mathrm{D}}$ program can be used for nonlinear analysis. The results are presented and discussed in terms of vertical stress and absolute total displacement. The contours of the vertical stress distribution along the central line in the backfilled vertical and inclined primary stope, after extracting the secondary stope, are depicted in Figures $3 \& 4$ respectively. It can be seen that, the contours of vertical stress show a non-uniform stress distribution. Also, the analysis revealed that, negative (e.g., tension) vertical stress occurs on the top of backfilled stope and slightly increases with depth (Figures $3 \& 4$ ).

The simulated vertical stress, along the central line, of the vertical and inclined backfilled primary stope at different height-to-width ratio $(\mathrm{h} / \mathrm{w})$, is shown in Figures $3 \& 4$ respectively. It is measured each $2.5 \mathrm{~m}$ apart on the center of backfilled stope column (e.g., the stope width is $5 \mathrm{~m}$ ). Figures $3 \& 4$, show that, the vertical stress is negative at the top of backfilled primary stope (e.g., relaxation zone), and then it increases slowly as depth extends downwards. It is unusual to immediately place backfill into extracted stope. Thus, this may lead to the deformation of the surrounded rock mass. Hence, it is strongly advised to place 
backfill into mined out stopes at earliest time to prevent any possible stope instability or falling rocks. The results of analysis also show the non-uniform contours distribution of the vertical stress along the central line of the vertical and inclined backfilled stope, Figures 3 \& 4 respectively. The backfilled column starts with a relaxation or tension zone on the top (e.g., failure region) then vertical stress converted to a compression stress as depth increases. The minimum vertical stresses (e.g., tensile stresses) are found to be -0.1MPa at the top portion of both vertical and inclined backfilled primary stope while the maximum vertical stresses occurred at the bottom of the backfilled stopes and they are $4.96 \& 3.94 \mathrm{MPa}$ respectively. Alternatively, tensile stress developments are shown in the top part (e.g., extend to shallow depth downwards) of backfilled primary stope which indicates failure condition (e.g., loss of confinement). In the light of this analysis, failure zone is shown at the top portion of backfilled primary stope (e.g., presented by tensile stress region).

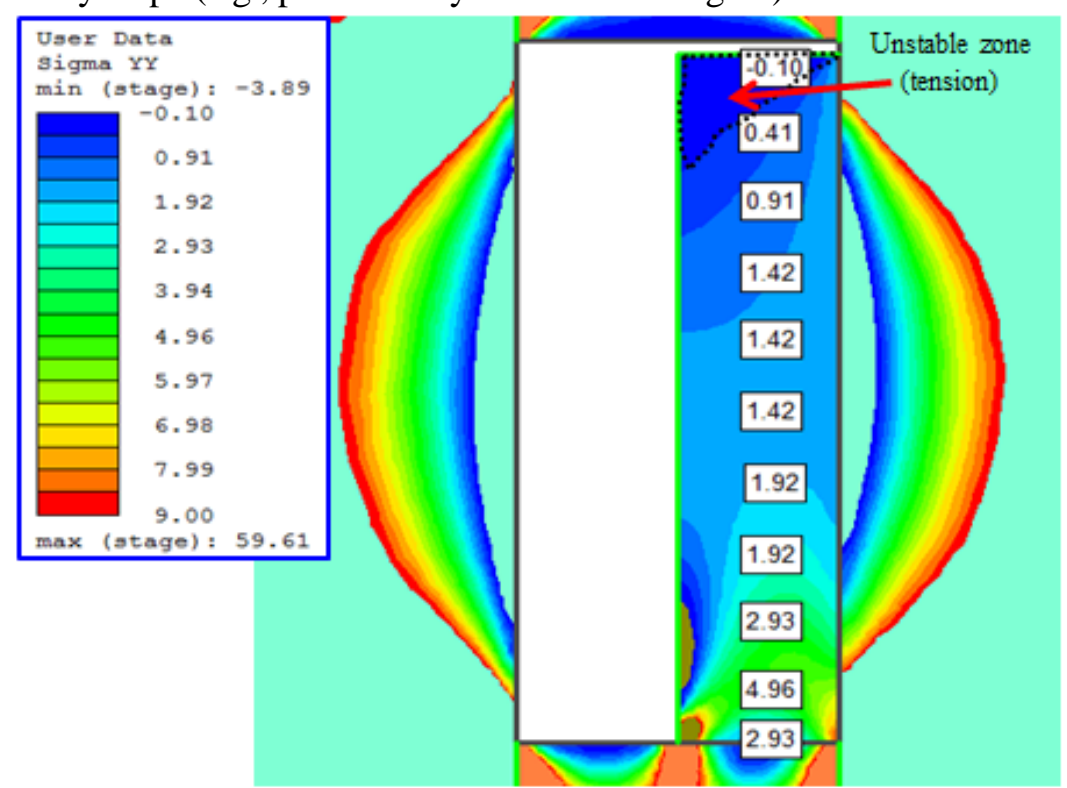

Fig. 3. Contours of vertical stress distribution along the central line of vertical backfilled primary stope

On the other hand, there is no deterioration occurred at the bottom of both vertical and inclined backfilled primary stope. Also, high stress concentration zones are developed at the crown and bottom of the vertical and inclined backfilled primary stope (reddish color) and transferred to the surrounded rock mass. Thus, in turn, indicates that backfill provides stability and good confinement to adjacent rock mass.

The vertical stress development and absolute total displacements, in the vertical and inclined backfilled primary stope, are shown in Figures $5 \& 6$ respectively and they are measured at various height-to-width $(\mathrm{h} / \mathrm{w})$ ratios (e.g., measured each $2.5 \mathrm{~m}$ apart) starting from the stope surface (e.g., at $0 \mathrm{~m}$ or $(\mathrm{h} / \mathrm{w})=$ zero) to the stope toe (e.g., at $25 \mathrm{~m}$ or $(\mathrm{h} / \mathrm{w})=5)$. 
Wael R. Abdellah and Mahrous A. Ali, stability analysis of vertical and inclined backfilled stope

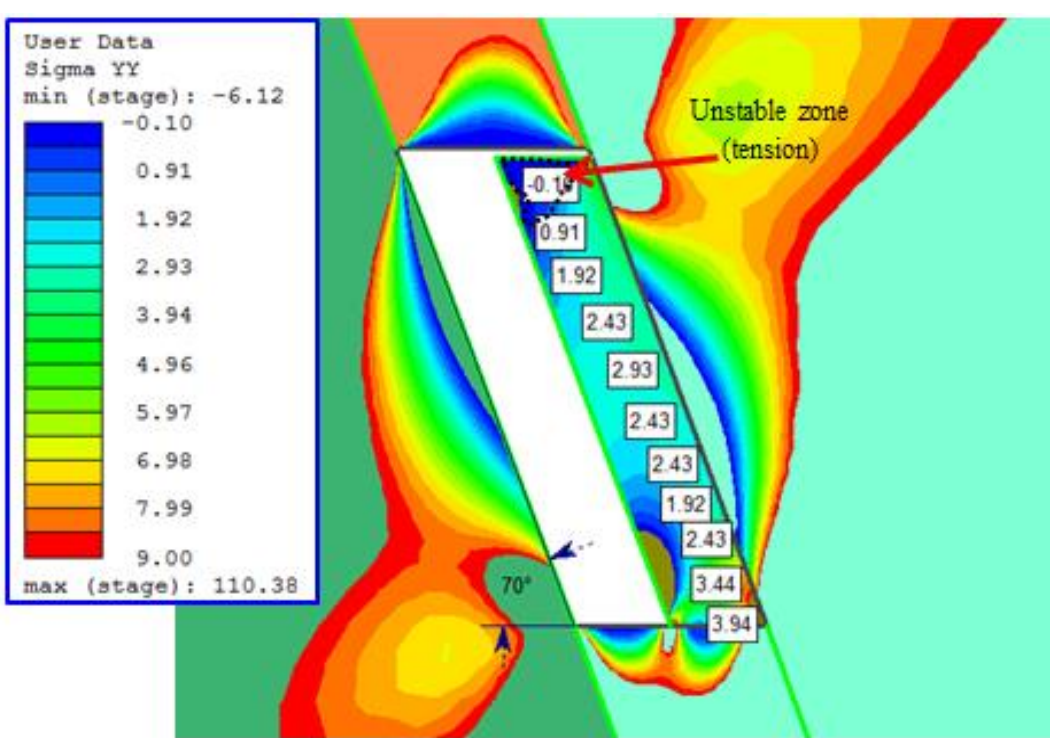

Fig. 4. Contours of vertical stress distribution along the central line of inclined backfilled primary stope

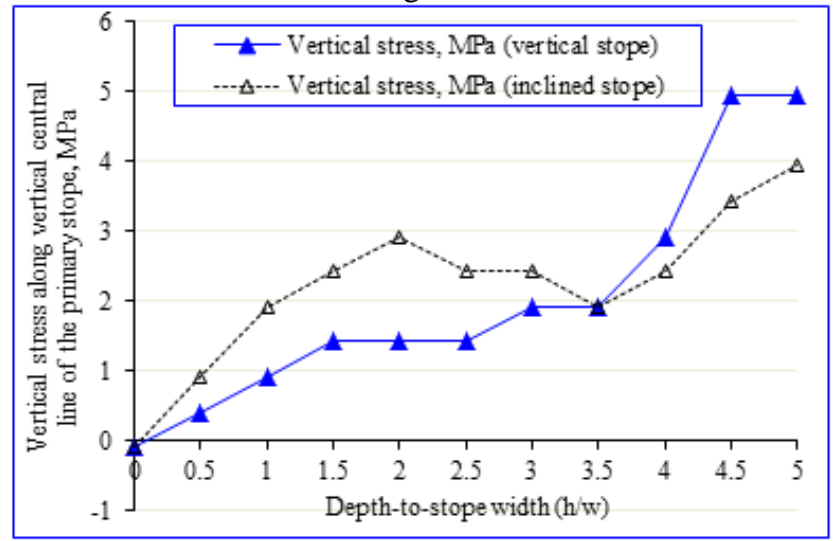

Fig. 5. The development of vertical stress at different depth-to-width ratios along the central line of vertical and inclined backfilled primary stopes

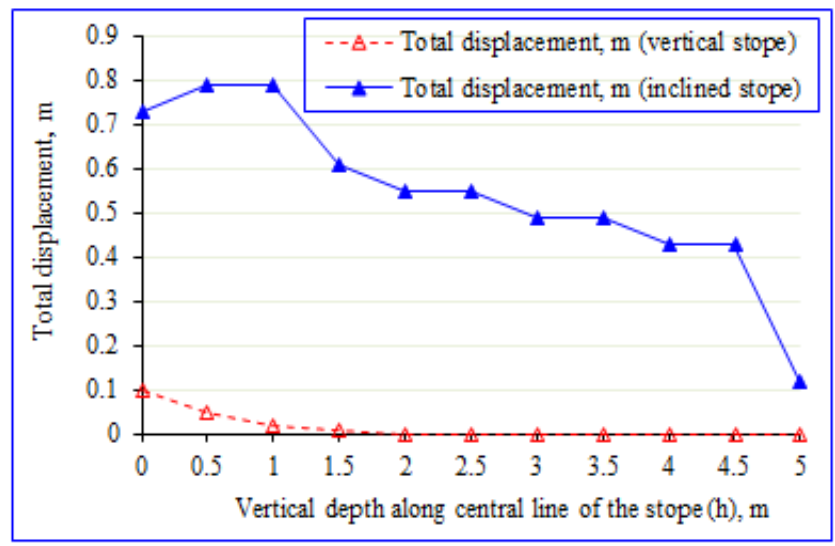

Fig. 6. Total displacement at different depth-to-width ratios along the central line of backfilled primary stopes 
Figure 6 shows that, the maximum total displacement occurred at the top of the vertical and inclined backfilled primary stopes (e.g., $0.1 \mathrm{~m}$ and $0.79 \mathrm{~m}$ correspond to the tensile stresses of $-0.1 \mathrm{MPa}$, Figure 5) respectively. This indicates that, there is a significant movement towards the adjacent secondary stope (e.g., mined out stope) only in the top of the backfilled column, which, in turn, suggesting possible minor failure may occur. The bottom of backfilled primary stope looks stable and has less displacement (e.g., displacement reduces downwards). Alternatively, the total displacement decreases as depth-to-width ratio increases. The minimum displacements for the vertical and inclined backfilled primary stope are $0 \mathrm{~m}$ and $0.12 \mathrm{~m}$ at the stope toe (e.g., correspond to vertical stresses of $4.96 \& 3.94 \mathrm{MPa}$, Figure 5) respectively. Thus, it means the backfilled stope is stable particularly at the bottom (e.g., where a backfill material was first cured and far away from the free face and void space of secondary stope).

\section{Conclusion}

Placement of backfill into extracted stopes is necessary in deep underground mines (e.g., particularly at high in-situ stress conditions/environments) in order to prevent any possible failure of the surrounding rock mass. The backfill placement should be immediately done after stope is extracted to avoid any rock mass deformation and stress build-up. For instance, the bottom of backfilled stope looks stable as backfill material was first cured and placed far away from the free face and void space of secondary stope. The results revealed that, for both vertical and inclined backfilled primary stopes, possible minor failure may occur in the top portion of backfilled stopes (e.g., tensile stress). Alternatively, the top part of backfilled primary stopes looks unstable compared to their bottom (e.g., looks more stable as positive stress and zero/small displacement are developed). Even though, the numerical modelling analysis is considered a powerful tool, it can be used to assess the stability of backfilled stopes and surrounded host rock. However, its results have to be confirmed by monitoring the exposed backfilled stope to blasting/vibrations in the mine and using the produced failure surface for validation. Also, in order to provide good-confinement to the host rock mass, an immediate and proper tight filling is necessary especially at the top of the stope to secure its stability. Furthermore, the filling material must be placed into stages to allow it to be cured before adding another layer. Also, it is imperative to allow proper period of curing time to achieve stable fill wall before extracting the adjacent secondary stope to backfilled primary stope. Fill strength at the top of backfilled column is reduced since maximum stress is developed at the bottom of the backfilled column compared to the top. Therefore, it is recommended to involve cement as a binding agent to improve the fill strength.

\section{Recommendations for future work}

For future research, additional numerical modelling has to be done to better understanding the behaviour of backfilled stopes (e.g., taking into account rock-fill interface behaviour, the effect of water on the response of backfill in stopes (e.g., pore pressure build-up due to backfill addition), effect of blast vibrations/loads on the stability of backfill, backfill segregation). Also, static analysis is insufficient to design/determine the strength requirement of the backfill. A 3-D modelling has to be conducted, adopting real mining sequences, to introduce the exact mining conditions/scenarios. 
Wael R. Abdellah and Mahrous A. Ali, stability analysis of vertical and inclined backfilled stope

\section{Nomenclature}

$\phi$ : Angle of internal friction of rock mass,

$\varphi$ : Angle of dilation of rock mass,

$\mathrm{C}$ : Cohesion of rock mass,

$\mathrm{K}$ : Horizontal-to-vertical stress ratio $\left(\mathrm{K}=\frac{\sigma_{h}}{\sigma_{v}}\right)$,

MASU: Massive sulphide rock mass (ore),

E: Modulus of elasticity of rock mass (Young's modulus),

MTSD: Meta-sediment rock mass (hanging wall),

NR: Norite rock mass (footwall),

$v$ : Poisson's ratio of rock mass,

$\mathrm{RS}^{2 \mathrm{D}}$ : Rock-soil two-dimensional finite element software,

$\sigma_{t}$ : Tensile strength of rock mass,

UCS: Unconfined compressive strength of rock mass, and

$\gamma$ : Unit weight of rock mass.

\section{Acknowledgements}

The authors acknowledge the support of Rocscience Inc. for getting a free two-week full-version of $\mathrm{RS}^{2 \mathrm{D}}$ (Rock-Soil two-dimensional finite-element analysis program). The authors are grateful for their support. For more information about $\mathrm{RS}^{2 \mathrm{D}}$ software, the reader is directed to the link: https://www.rocscience.com/rocscience/products/rs2

\section{REFERENCES}

[1] Muhammad Zaka Emad, 2013. Dynamic Performance of Cemented Rockfill under Blast-Induced Vibrations. Ph.D. thesis, McGill University, Montreal, Quebec, Canada, December 2013.

[2] Manoj N. Badge and Hani S. Mitri, 2015. Numerical analysis of backfill face stability. Procedia Earth and Planetary Science, 11 (2015), 173-179.

[3] Hassani, F. and Archibald, J.F. 1998. Mine backfill. CIM, CD-ROM.

[4] Kump, D. 2001. Backfill - Whatever it takes. Mining Engineering 53(1): 50-52.

[5] Li Li and Michel Aubertin, 2007. An improved solution to estimate the stress state in subvertical backfilled stopes. OttawaGeo2007 and Canadian Geotechnical Journal, 2008, 45(10): 1487-1496, 10.1139/T08-060.

[6] Jung, S.J. and Biswas, K. 2002. Review of current high density paste fill and its technology. Mineral Resources Engineering 11(2): 165-182.

[7] Doerner, C.A.C., Effect of delayed backfill on open stope mining methods, in Mining Engineering2005, University of British Columbia: Vancouver BC Canada.

[8] Kurakami, T. et al., Mining with backfill at the Hishikari Mine, Japan. Gospodarka Surowcami Mineralnymi 2008. 24: p. 197 - 212.

[9] Grice, A.G. Recent Minefill Developments in Australia. in Minefill 2001: Proceedings of the 7th International Symposium on Mining with Backfill 2001. Seatle WA USA: Society of Mining, Metallurgy \& Exploration.

[10] Henderson, A., G. Jardine, and C. Woodall, The implementation of paste fill at the Henty gold mine, in Minefill98: The Sixth International Symposium on Mining with Backfill, M. Bloss, Editor 1998, Australasian Institute of Mining and Metallurgy: Brisbane Australia. p. 299 - 304.

[11] Currie, R., The preparation of pastefill and its use at some Canadian mines, in Minefill98: The Sixth International Symposium on Mining with Backfill, M. Bloss, Editor 1998, Australasian Institute of Mining and Metallurgy: Brisbane Australia. p. 325 - 330. 
[12] Belem, T., Benzaazoua, M. and Bussière, B. 2000. Mechanical behaviour of cemented paste backfill, Proceedings of 53th Canadian Geotechnical Conference, 15-18 October 2000, Montréal, 1: 373- 380.

[13] Belem, T., Benzaazoua, M., Bussière, B. and Dagenais, A.-M. 2002. Effects of settlement and drainage on strength development within mine paste backfill. Proceedings of Tailings and Mine Waste'02, 27-30 January 2002, Fort Collins, Colorado, Balkema: Rotterdam: 139-48.

[14] Belem, T., El Aatar, O., Benzaazoua, M., Bussière, B. and Yilmaz, E. 2007. Hydrogeotechnical and geochemical characterization of column consolidated cemented paste backfill. 9th International Symposium in Mining with Backfill, April 29-May 2, 2007, Montreal, Qc. CIM, CD-ROM.

[15] Benzaazoua, M., Belem, T., Bussière, B. and Ouellet, S. 2002. Évolution des propriétés des remblais en pâte: principaux paramètres d'influence. 17e Colloque Contrôle de terrain, Vald'Or. Association Minière du Québec.

[16] Aubertin, M., Li, L., Arnoldi, S., Belem, T., Bussière, B., Benzaazoua, M. and Simon, R. 2003. Interaction between backfill and rock mass in narrow stopes. $12^{\text {th }}$ Panamerican Conference on Soil Mechanics and Geotechnical Engineering and $39^{\text {th }}$ U.S. Rock Mechanics Symposium. PP. 1-8.

[17] Handy, R.L. 1985. The arch in soil arching. Journal of Geotechnical Engineering, ASCE 111(3): 302-318.

[18] Hunt, R. E. 1986. Geotechnical engineering analysis and evaluation. McGraw-Hill, New York.

[19] Harrop-Williams, K. 1989. Arch in soil arching. Journal of Geotechnical Engineering 115(3): 415-419.

[20] Drescher, A., 1991. Analytical methods in bin-load analysis. Elsevier, Amsterdam.

[21] Rocscience Inc. RS2, "Rock and Soil 2-dimensional analysis program", 2016. 439 $\begin{array}{lllllll}\text { University Ave } & \text { Ste } 780 & \text { Toronto, } & \text { Ontario } & \text { M5G } & \text { 1Y8 }\end{array}$ (https://www.rocscience.com/rocscience/products/rs2).

[22] Abdellah, W., Mitri, H. S., Thibodeau, D., and Moreau-Verlaan, L. (2012). Stochastic evaluation of haulage drift unsatisfactory performance using random Monte-Carlo simulation, Int.J.Mining and Mineral Engineering (IJMME). Vol.4 No.1.2012 pp. 63-87.

[23] Abdellah, W. (2015). "Parametric stability analysis of room and pillar method in deep coal mines". Journal of Engineering Sciences (JES). University of Assiut, Faculty of EngineeringVol. 43, No. 2- March (2015), PP. 1440 - 1451. 

تحليل استقرار بلوكات الخام الرأسية والمائلة المملوءة بمواد الردم/الحشو

الملخص العربي:

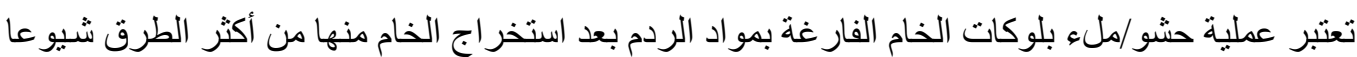

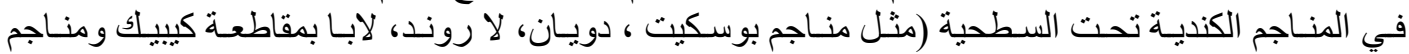

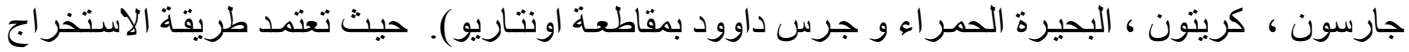

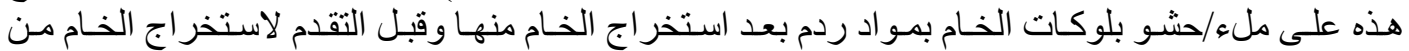

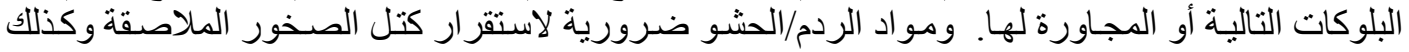

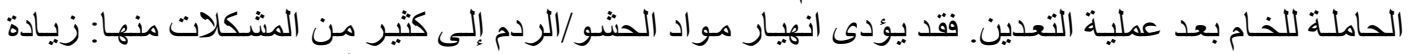

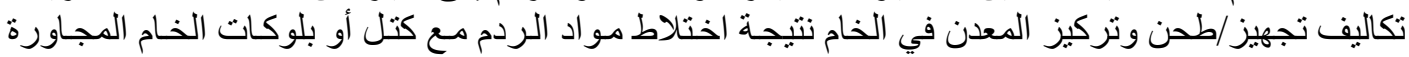

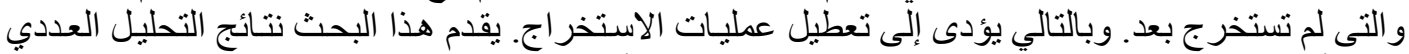

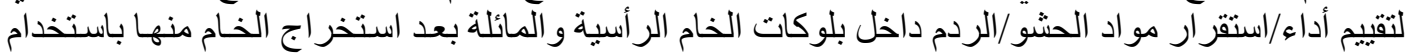

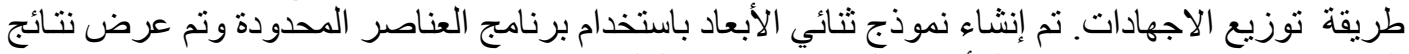

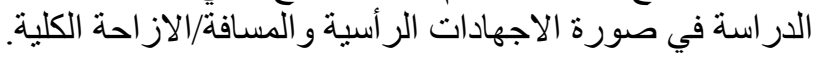

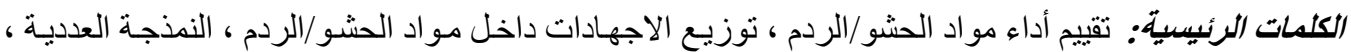

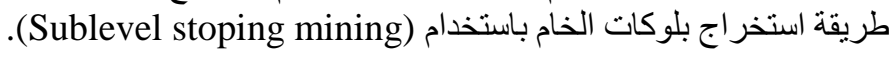

